\title{
Changes in biodiversity and trade-offs among ecosystem services, stakeholders, and components of well-being: the contribution of the International Long-Term Ecological Research network (ILTER) to Programme on Ecosystem Change and Society (PECS)
}

Manuel Maass $^{1}$, Patricia Balvanera $^{1}$, Patrick Bourgeron ${ }^{2}$, Miguel Equihua $^{3}, \underline{\text { Jacques Baudry }}^{4}, \underline{\text { Jan Dick }}^{5}, \underline{\text { Martin Forsius }}^{6}, \underline{\text { Lubos }}^{12}$

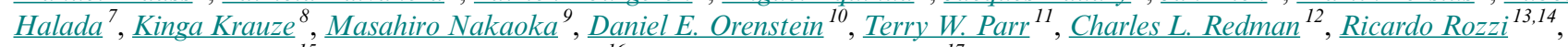
Margarida Santos-Reis $^{15}$, Anthony M. Swemmer ${ }^{16}$ and Angheluta Vă dineanu $^{17}$

\begin{abstract}
The International Long-Term Ecological Research (ILTER) network comprises $>600$ scientific groups conducting sitebased research within 40 countries. Its mission includes improving the understanding of global ecosystems and informs solutions to current and future environmental problems at the global scales. The ILTER network covers a wide range of social-ecological conditions and is aligned with the Programme on Ecosystem Change and Society (PECS) goals and approach. Our aim is to examine and develop the conceptual basis for proposed collaboration between ILTER and PECS. We describe how a coordinated effort of several contrasting LTER site-based research groups contributes to the understanding of how policies and technologies drive either toward or away from the sustainable delivery of ecosystem services. This effort is based on three tenets: transdisciplinary research; cross-scale interactions and subsequent dynamics; and an ecological stewardship orientation. The overarching goal is to design management practices taking into account trade-offs between using and conserving ecosystems toward more sustainable solutions. To that end, we propose a conceptual approach linking ecosystem integrity, ecosystem services, and stakeholder well-being, and as a way to analyze trade-offs among ecosystem services inherent in diverse management options. We also outline our methodological approach that includes: (i) monitoring and synthesis activities following spatial and temporal trends and changes on each site and by documenting cross-scale interactions; (ii) developing analytical tools for integration; (iii) promoting trans-site comparison; and (iv) developing conceptual tools to design adequate policies and management interventions to deal with trade-offs. Finally, we highlight the heterogeneity in the socialecological setting encountered in a subset of 15 ILTER sites. These study cases are diverse enough to provide a broad cross-section of contrasting ecosystems with different policy and management drivers of ecosystem conversion; distinct trends of biodiversity change; different stakeholders' preferences for ecosystem services; and diverse components of well-being issues.
\end{abstract}

Key Words: ecosystem integrity; ecosystem services; ILTER; long-term ecological research; PECS; site-based research; socio-ecosystem research; trade-offs among ecosystem services; transdiscipline

\section{INTRODUCTION}

The recognition of the global dimensions of many socioenvironmental issues has prompted the development of worldwide initiatives to address them. The endeavor is so far reaching and complex that no single country or institution can approach it alone, and these efforts soon have focused on international and multi-institutional cooperative initiatives. The International Long-Term Ecological Research (ILTER) network was created 22 years ago as a way to expand the then already 10year-old US-LTER initiative. It is currently a growing global network, with 40 country-level members, encompassing over 600 sites spread across 5 continents. Through research coordination at local, regional, and global scales and by improving comparability of long-term ecological data, ILTER aims to generate scientific information at multiple scales useful to policy making, decision makers, land managers, educators, local communities, and the general public interested in environmental issues. Its flexible research agenda and its commitment for longterm and site-based research make ILTER a natural partner for multiple global initiatives. In fact, many ILTER members have already been active in many international programs and research initiatives (e.g., Parr 2013, Maass and Equihua 2014).

Important topics of research at most ILTER sites are the effects of ecosystem transformation, biodiversity loss, and change in ecosystem integrity. Both biodiversity and ecosystem functions are affected by multifaceted and multiple scale socioenvironmental pressures such as climate change, land-use changes, pollution, overexploitation of natural resources, and invasive alien species, providing a major challenge for the sustainable management of the key ecosystem services (ES;

\footnotetext{
${ }^{1}$ Instituto de Investigaciones en Ecosistemas y Sustentabilidad (IIES), Universidad Nacional Autónoma de México (UNAM), México, ${ }^{2}$ Institute of Arctic and Alpine Research (INSTAAR), University of Colorado at Boulder, USA, ${ }^{3}$ Instituto de Ecología, A.C. (INECOL), México, ${ }^{4}$ Institut National de la Recherche Agronomique (INRA), SAD-Paysage, France, ${ }^{5}$ Centre for Ecology and Hydrology, UK, ${ }^{6}$ Finnish Environment Institute (SYKE), Finland, ${ }^{7}$ Institute of Landscape Ecology SAS, Slovakia, ${ }^{8}$ European Regional Centre for Ecohydrology, PAS, Poland, ${ }^{9}$ Akkeshi Marine Station, Field Science Center for Northern Biosphere, Hokkaido University, Japan, ${ }^{10}$ Faculty of Architecture and Town Planning, Technion - Israel Institute of Technology, Israel, ${ }^{11}$ Centre for Ecology \& Hydrology, Lancaster Environment Centre, Lancaster, UK, ${ }^{12}$ School of Sustainability, Arizona State University, USA, ${ }^{13}$ Sub-Antarctic Biocultural Conservation Program, University of North Texas, USA, ${ }^{14}$ Institute of Ecology \& Biodiversity, Universidad de Magallanes, Omora Ethnobotanical Park, Puerto Williams, Chile, ${ }^{15}$ Centre for Ecology, Evolution and Environmental Changes (cE3c), Faculdade de Ciências da Universidade de Lisboa, Portugal, ${ }^{16}$ South African Environmental Observation Network (SAEON), South Africa, ${ }^{17}$ Research Centre for Systems Ecology and Sustainability, University of Bucharest, Romania
} 
Schröter et al. 2005, Mooney et al. 2009, Aherne et al. 2012, Forsius et al. 2013). The provision of sustainable level of ecosystem services has become a major concern both at the national level (e.g., UK NEA 2011) and at the continental scale (Maes et al. 2012). Nonetheless, the losses of biodiversity and ecosystem services continue more rapidly than ever (MA 2005, Pereira et al. 2010, Ehrlich et al. 2012). Even when biodiversity loss is not reported systematically, change in communities and ecosystem degradation over time has been systematically observed, as shown by Dornelas et al. (2014). This loss of ecosystem integrity or degradation over time will have specific consequences for ecosystem services delivery through changes in the dominant traits of the community and other key ecosystem components affected, e.g., soil moisture and nutrient content, that will, in turn, change the pattern of ecosystem processes.

Because of their multiple overlapping theoretical interests and applied activities, we propose that the ILTER network and the Programme on Ecosystem Change and Society (PECS) are natural partners that can work synergistically toward their shared objectives and goals. PECS is a new initiative fostered by the International Council for Science (ICSU) within its Global Change Framework aiming to integrate research on the stewardship of socio-ecosystems by understanding the flux of services and control factors that modulate their dynamics. This leverages current attempts to understand the relationships among natural and human capital, human well-being, livelihoods, inequality, and poverty (Carpenter et al. 2012). The ILTER wide range of ecological and social conditions makes a compelling case for collaborating with PECS. The goals, objectives, and approaches of these two efforts very well complement one another.

Our aim in this paper is to examine and develop the conceptual basis for such collaboration. We explicitly explore the potential for collaboration between the ILTER and PECS, initially assessing how the ILTER vision, mission, and approach are consistent with that of PECS, and then describing how a coordinated effort of several contrasting ILTER sites, following the network philosophy and approach, can contribute to a better understanding of how policies and technologies that affect sustainable delivery of ecosystem services change across sites. We suggest doing this by using biodiversity (or ecosystem integrity as its operative proxy) and human well-being as key response variables in analyses of how these variables change under different ecosystem management regimes and in diverse social-ecological settings. We are particularly interested in the identification of trade-offs in current and future ecosystem services provision inherent in management and policy alternatives and as a function of diverse stakeholders' objectives and components of well-being. We define well-being in a broad sense including economic resources, but also noneconomic aspects of peoples' life, such as what they do, what they can do, how they feel, the social and natural environment in which they live, and their everyday activities, like their participation in the political process, and the factors shaping their personal and economic security (Stiglitz et al. 2009).

This paper is an invited contribution to a Special Feature in Ecology and Society on the "Programme on Ecosystem Change and Society (PECS): Knowledge for Sustainable Stewardship of Social-ecological Systems." The emphasis here is on the contribution of ILTER to PECS. Those readers interested in a more detailed description on the program, please refer to other contributions to this Special Feature (http://www.ecologyandsociety. org/issues/view.php?sf=106), as well as to Carpenter et al. 2009, 2012, the web site of PECS in ICSU (http://www.icsu.org/whatwe-do/interdisciplinary-bodies/pecs), and PECS's home page (http://www.pecs-science.org).

\section{ILTER'S VISION, MISSION, AND APPROACH}

ILTER's distinctive strength is the long-term research and monitoring of key ecosystem patterns and processes in a large set of sites across the planet. This approach allows assessment of slow, unexpected, as well as abrupt changes in ecosystems. Also, through the global network of sites, it can contribute to the understanding of how local processes scale up to global and back to local, and how contrasting ecosystems respond to similar drivers (http://www.ilternet.edu; Vaughan et al. 2007, Parr 2013). Therefore, the network is very well positioned to inform policy and management decisions by addressing temporal (long-term) and spatial (international network) scales seldom accounted for in scientific research. Although historical emphasis of ILTER has been on ecological patterns and processes often within reserves, a long-term social-ecological research approach (LT"SE" R) is been increasingly adopted worldwide (Shibata and Bourgeron 2011, Rozzi et al. 2012, Singh et al. 2013, Maass and Equihua 2014, 2015, Li et al. 2015). This new perspective holds societies and their dynamics as key components of integrated socioecosystems, and not necessarily threats to the natural world (Grimm et al. 2000, Redman et al. 2004, Haberl et al. 2006, Maass and Equihua 2015). As an example, a new strategic research initiative within the US-LTER community has been launched called Integrative Science for Society and the Environment (ISSE), proposed to elevate environmental science to a new level of integration, collaboration, and synthesis necessary for addressing current and emerging environmental research challenges (Collins et al. 2011).

The long-term presence of ILTER allows for the development of long-term links to local stakeholders over diverse social and ecological ranges. Indeed, stakeholder integration is one of the emphases of the burgeoning number of LTSER platforms within the network. The site-based research character of ILTER "is one of its most important assets, [allowing] not only capacity building and the accumulation of knowledge through time, but also the development of the necessary trust between the academic community and the local stakeholders required for transdisciplinary research approach" (Maass and Equihua 2015:227).

\section{ILTER AND PECS}

PECS and ILTER play key roles in helping to deliver the strategic research agenda of "Future Earth" (2014). ILTER has a particularly important role within Future Earth's research platform because it is a site-based program with a global emphasis on measuring, understanding, and modeling changes in socioecosystems on the ground. Although it is recognized that there is no comprehensive system currently in place for global assessments of ecosystem services (Tallis et al. 2012) work toward the development of essential biodiversity variables (GEOSS 2005, Pereira et al. 2013) and a better understanding of how to account for socioeconomic drivers of change (Andrew 2014) are providing the basis for more effective systems. As a global network of over 
600 sites providing long-term data on ecosystem change and an increasing resource for social-ecological research, ILTER provides one of the few data resources for the monitoring and research needed to underpin Future Earth's theme of "observing and attributing change." For example, ILTER when combined with complementary data from remote sensing, participatory monitoring involving citizens, and public sources recording socioeconomic variables will contribute to answering Future Earth questions such as the following: "What are the historic and current status and trends of biodiversity, ecosystems, and their services at different scales?" and "What models do we need to integrate global environmental and socioeconomic data to support progress toward global sustainable development, particularly in less developed countries?" Answers to these questions will not only contribute to scientific assessments such as the Intergovernmental Panel on Climate Change (IPCC) and the Intergovernmental Science-Policy Platform on Biodiversity and Ecosystem Services (IPBES; Díaz et al. 2015), but the permanent site infrastructure and observations maintained within ILTER sites will also provide a long-term component of the Global Earth Observation System of Systems (GEOSS), a global public infrastructure aimed at achieving comprehensive, coordinated, and sustained observations of the Earth system, designed to improve monitoring of the state of the Earth, increase understanding of Earth processes, and enhance prediction of the behavior of the Earth system (GEOSS 2005).

Carpenter et al. (2009) highlighted the need to assess the management of ecosystem services flows and evaluate its effects on human well-being when analyzing the type of science required beyond the Millennium Ecosystem Assessment (MA). To tackle these knowledge gaps, Carpenter et al. (2012), in a paper describing the vision and goals of PECS, highlighted the need to strengthen the support for place-based, long-term, socialecological research. Carpenter et al. (2009) also warned that some policies and practices intended to improve ecosystem services and human well-being were based on untested assumptions and sparse information. Remedying this situation has proven to be a difficult task not only because of the complexity of transdisciplinary research required to understand the ecosystem service/well-being relationship, but also because this relationship is locally specific. As Rozzi (2012) pointed out, inhabitants of a particular place develop particular socio-cultural habits that are highly correlated with the particular habitat in which their culture has developed. The diversity of ecosystems and concurrent diversity of cultural settings in the world is enormous and dynamic. Therefore, it is indispensable to "consider the full ensemble of processes and feedbacks, for a range of biophysical and social systems, to better understand and manage the dynamics of the relationship between humans and the ecosystems on which they rely" (Carpenter et al. 2009:1305). It is precisely on these lines where the collaboration between ILTER and PECS can contribute most productively. Given the long-term and site-based characteristic of the ILTER network, and particularly with regard to those sites with a socialecological research orientation, it would be possible to foster the study of how ecosystem services are generated, as well as the relationships among natural capital, human well-being, livelihoods, inequality, and poverty under a diverse range of social-ecological settings (type of ecosystem; land use cover, current and historic technological and institutional management practices; and cultural perspectives and worldviews).
An ILTER/PECS collaboration should be built within the socioecosystem conceptual framework, in which humans are not seen just as a species taking advantage of ES, but as part of a complex human-biological-physical entity that emerged from the ecosystems themselves, and have coevolved via integrated biophysical and cultural processes occurring at different scales of time and space (Collins et al. 2011, Maass 2012). The socioecosystem concept not only recognizes the inescapable dependence of humans on ecosystem processes (because we created from them), but also acknowledges the technological ability of humans to deeply intervene in such processes. Levin (1999) argues that the biosphere is a complex adaptive system and by exploring how such systems work, we can determine how they might fail: how resilient are the ecosystems or how much degradation can they withstand before starting to collapse (Costanza and Farber 2002). The sustainability challenge is how to benefit from ecosystem services without altering the integrity of ecosystems to a point that hinders those life support services (Lambin and Meyfroidt 2011).

It has been particularly difficult to properly acknowledge and evaluate the ecological trade-offs inherent in human alteration of ecosystems. In fact, as Carpenter et al. (2009) point out, making trade-offs explicit is a core function of ecosystem assessments. They also emphasize that understanding the true social value of nonmarketed ecosystem services depends on the ways that particular services are used by different stakeholders. Therefore, for the identification of changes in biodiversity and trade-offs among ecosystem services, defining and querying stakeholders and components of well-being from the perspective of stakeholders are of utmost importance. That is why our major focus in our ILTER/PECS collaboration is placed on those subjects.

\section{General approach and focus}

Biodiversity plays a key role in the structure and dynamics of ecosystems and so it is essential for maintaining basic ecosystem processes and supporting ecosystem functions (Cardinale et al. 2012, Naeem et al. 2012). Linking biodiversity, which is mostly a structural characteristic of the ecosystem, with ecosystem services, which is a more functional aspect, is a challenge. Biodiversity changes through ecosystem management are linked to ecosystem auto-organization process, which in turn define their resilience, and thus is a basic dimension of ecosystem integrity maintenance. Therefore, our approach is to use ecosystem integrity as an operational proxy of biodiversity. In fact, maintaining ecosystem integrity through the protection of biodiversity (habitats and ecosystem functions) is key for assuring a sustainable supply of goods and services to human societies. Like Bridgewater et al. (2014) and Equihua et al. (2014), we believe that ecosystem integrity defines an ecosystem in a condition where its structure and functions are not impaired (auto-organization dynamics alone are driving the system); but to be practical, it can be assessed by comparing the current status of location against a baseline of structure and processes established for the same type of biome at a specified time. Clearly, changes in integrity take place through ecosystem degradation, and so one is the mathematical complement of the other. Trade-off analysis of ecosystem services requires the investigation of the complexities of ecology so the economic assessment does not dominate the valuation process. This, in turn, can further help in understanding the effects of human policies and their impacts on both 
ecosystems and human welfare (Farber et al. 2006). In fact, this valuation process is becoming part of the LTER approach as it evolves from a strict ecological to a more social-ecological research orientation (from LT"E"R to LT"SE"R).

One of the difficulties in evaluating ecological trade-offs is the current over-reliance on monetizing of ecosystem services. Spangenberg et al. (2014) has pointed out that this is a two-headed problem. On the one hand, economic values are measurements of subjective usefulness of an output of an ecological process and thus are a social construct. Therefore, the recognition and valuation of any particular output of an ecological process as a service will vary between different socio-cultural settings, and even between stakeholders in the same geographical area. In this respect, the comprehensive long-term ecological and socialecological data available from the ILTER sites provide an excellent platform for analysis, as well as for site-scale application of the different mapping and modeling tools. Several ILTER-based studies have already been conducted along these lines (e.g., Vadineanu et al. 2003, Maass et al. 2005, Vadineanu 2007, Ohtsuka et al. 2009, Forsius et al. 2013, Dick et al. 2014, Fu and Forsius 2015, Holmberg et al. 2015). With this accumulated and expanding experience, our goal is to contribute novel conceptual and methodological approaches, simple (not simplistic) enough to be implemented in highly heterogeneous and contrasting social-ecological settings. By emphasizing the transdisciplinary approach to assessing and valuing ecosystem services (incorporating stakeholders and expert knowledge and using multiple disciplinary approaches), we propose both a capacity building effort, as well as a data gathering one. We propose to incorporate into this effort not only as much worldwide variation as possible, but also to integrate into the research program as many LTER site/platforms as possible, despite the differences in economic and human resources that exist between them. By simplifying the methodologies, we hope to increase site participation, and understand complexity through conceptual integration and synthesis of the many, instead of through detailed analysis of the few. For example, through an initial survey utilizing the presence and absence approach, a comprehensive list of ecosystem service indicators has been developed in the LTEREurope community (Dick et al. 2014).

A second problem identified by Spangenberg et al. (2014) is the fact that ecosystem functions are emergent properties of the natural system, not artifacts or social constructs made and controlled by humans. Therefore, it is essential to separate the monetary valuation of individual services from the complex ecological processes sustaining them, to avoid the mistake of suggesting that services flow effortlessly and freely from ecosystems to beneficiaries. Following Spangenberg et al. (2014), we adopt a "cascade" process analysis where use of value attribution turns biophysical ecosystem functions into ecosystem services potential, which then require humans to mobilize, appropriate, and (frequently although not always) commercialize them. These authors extend the "cascade" analogy to suggest that the reverse process analysis, called "stairways" planning process, encompasses a full cycle of ecosystem services generation and management (Spangenberg et al. 2014).

Our approach aims at overcoming the difficulties of evaluating trade-offs by conceptually distinguishing ecosystem services, i.e., the benefits people obtain from the ecosystem (MA 2005), from ecosystem patterns and processes that deliver the former. We consider herein that the latter are indicators of ecosystem integrity (EI), itself associated with the characteristics of nature's sustainability and resilience. Of course both are socialecologically relevant; however, some ecosystem processes do not require transformation in order to be appropriated by society and, therefore, there is no ecological trade-off (ET) involved. However, there could be a social trade-off (ST) referring to the cost of opportunity lost for not transforming the ecosystem. We call it social trade-offs because it is not only an economic cost involved but also a socio-cultural cost, e.g., political, scientific, legal, religious, artistic, etc. (Gómez-Baggethun and de Groot 2007, Peterson et al. 2010), as well as the cost of protecting its ecosystem's integrity (to maintain its original/natural or unperturbed condition).

Using the Millennium Assessment classification (MA 2005) as an example, all "supporting" and many "regulating" and "cultural" services do not require ecosystem transformation. Thus, the less transformed ecosystem, i.e., with high ecological integrity, provides the highest levels of services (green lines in Fig. 1). However, most "provisioning" services and some "cultural" services do require an ecosystem manipulation to be appropriated by society (blue lines in Fig. 1). Therefore, there is an ecological and socio-cultural trade-off. The more we manipulate the ecosystem, the more provision services we may get from it, but there is a cost in degrading its integrity and, therefore, in its sustainable capacity, e.g., the cost of restoration, to provide these and other services (see also de Groot et al. 2010). Under this framework, ecological trade-off (ET) becomes equivalent to 100 minus the proportion of ecosystem integrity (EI) lost during the appropriation process (a working example appears in Fig. 2). In the same way social trade-offs (ST) become equivalent to 100 minus the actual ecosystem services (ES; primarily provisioning, but perhaps also cultural) obtained in the appropriation process. In summary, a net service (NS) provided by the ecosystem should be calculated as the result of two components: the added benefits (both ES + EI) minus the trade-off cost (both ST + ET), therefore $\mathrm{NS}=(\mathrm{ES}+\mathrm{EI})-(\mathrm{ST}+\mathrm{ET})$.

Fig. 1. Relationship between ecosystem services, ecosystem transformation, and ecosystem integrity. See the text for an explanation and discussion of scenarios A, B, C, and D.

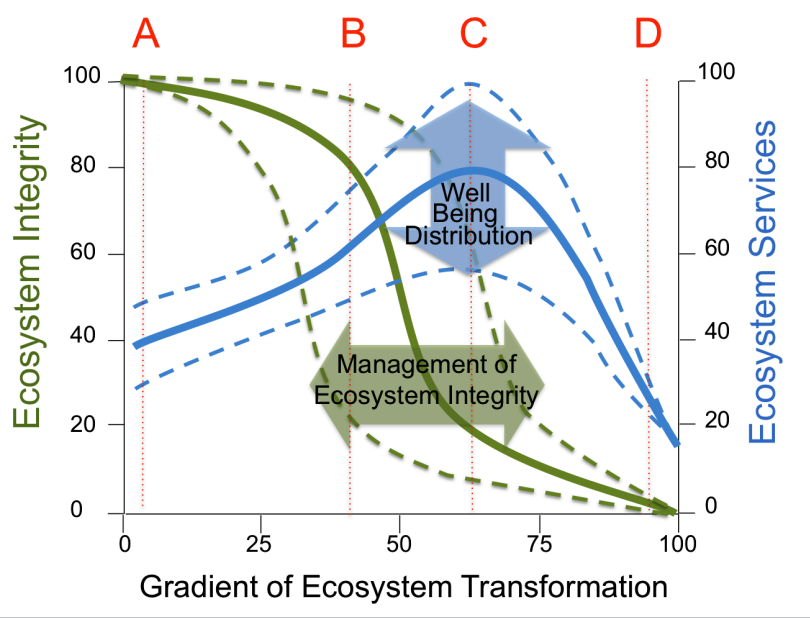


Fig. 2. Calculation of net service under four idealized scenarios presented in Figure 1. See the text for an explanation and discussion of scenarios A, B, C, and D. (All units are in $\%)$.

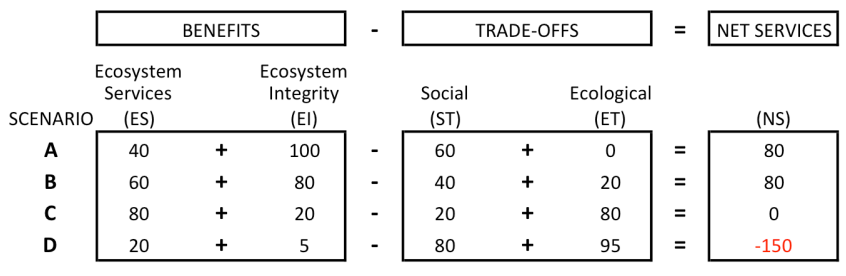

How can this framework be applied to particular cases? We hypothesized four scenarios (ecosystem states) as illustrated in Figure 1 (red dotted lines). The calculation of the net service (NS) provided by the ecosystem is shown in Figure 2. All units are presented as a percentage of the "ideal" condition (well preserved, with high integrity, resistant and resilient sustainable ecosystem):

- Scenario A corresponds with a well-preserved ecosystem, e.g., a natural reserve, a sanctuary, a relict area, etc., in which the net ecosystem services will be high because we not only get a full suite of support and regulation processes that are the products derived from high ecosystem integrity (EI), but we also receive provisioning and cultural ecosystem services (ES) with a very low ecological tradeoff cost (ET). Under this conservation scenario, social trade-offs could vary depending on the local socio-cultural conditions (nature vs. technology prone cultures). On this exercise we calculated $60 \%$ trade-off, but it could be much lower if the local community values conservation as an important asset.

- In scenario B, in a well-managed ecosystem, e.g., a wellkept rangeland, a diverse forest plantation with a multilayer canopy, an agro-silvo pastoral system, a coastal lagoon, etc., added services come at little cost, because with transformation we get an increase of ecosystem services with relatively small loss of ecosystem integrity (low ecological trade-off). Under such a system, the social tradeoff is low because the opportunity cost is also reduced (part of the opportunity has been taken).

- In scenario C, in an intensive managed system, e.g., induced pastures, extended fish farms, large-scale monoculture crops, large cities, etc., although the ecosystem services benefits are very high, because of the large increase in provisioning services, the ecosystem integrity is significantly reduced; therefore, ecological trade-off (ET) is high. In this case, the social trade-off (ST) is low because there is very low opportunity cost (almost all the opportunity was utilized). However, the benefits of transforming the system are negated by an equal or larger ecological cost.

- The fourth and least desirable scenario (D), is a highly disturbed ecosystem, e.g., a eutrophicated lake, a mine pit, an abandoned eroded crop field, etc., in which the ecosystem integrity (EI), as well as ecosystem services benefits are very low because of a highly degraded condition with high social and ecological costs (ST and ET). There is not only a lack of support and regulation processes provided by these highly transformed ecosystems, but also, as the negative net service clearly shows, the system is a source of ecological degradation.

In a human-dominated environment, social factors, such as skills, management regimes, and the type of technology used to transform the ecosystem, are also factors in ecosystem services production (Spangenberg et al. 2014). Therefore, different arrangement (and technological) approaches will produce variations of ecosystem response in terms of services provided and ecosystem integrity reduction (green dashed lines and big green arrow in Fig. 1). Also, depending on the variety of stakeholders and the type and distribution of the benefits, differences in ecosystem service bundles will be provided and wellbeing will vary (blue dashed lines and big blue arrow in Fig. 1). This last point is particularly important because, as Reyers and colleagues (2013) point out, the complex, interconnected, dynamic nature of ecosystem services has thus far prevented researchers from understanding how changes in human wellbeing feed back to ecosystem integrity and affect the provision of ecosystem services. This has impeded our understanding of the complex trade-offs associated with sustainability-related policy and management decision. Reyers and colleagues (2013) convincingly argue for the importance of using a socio-ecosystem approach to tackle the problem.

We suggest using this conceptual model of a hypothesized relationship between transformation, integrity, delivery of various ecosystem services, and well-being (Fig. 1) as a heuristic tool to foster the proposed ILTER/PECS collaboration. It will certainly require fine-tuning and clear definitions, e.g. operational definition of axis variables and ways of measuring them, but it is simple enough to be applied to any type of land cover, productive system, or stakeholder participation. Evaluating the same variables in diverse sites and social-ecological settings will elucidate the complexities of the trade-off problem. Also, when applying the framework to real-life cases, some casespecific issues may arise, thus requiring fine-tuning of trade-offs calculations. For example, in cases when social trade-off (ST) involves consideration of priorities other than ecosystem services, e.g., cutting down a forest to build a city, here the ecosystems are not being transformed for a provisioning ecosystem service, but for a nonecosystem services-related land use. Thus the calculated opportunity costs would be more than only the loss of a provisioning ecosystem services.

By analyzing the same variables in different sites we can also understand spatial scale issues, and by continuing the analysis in the framework of a long-term research program will further reveal temporal dynamics of the trade-offs, e.g., panarchy dynamics (Kinzig et al. 2006, Dick et al. 2011). Comparing and synthesizing results originating from a high variety of stakeholder's desires and transformation possibilities under different socioeconomic settings, will help us to understand the complex reality in which humans are embedded. It will also help us to recognize the complexity of natural systems, the ecological knowledge available to work with that complexity, and the amount of effort, or transaction costs, necessary to seriously and effectively engage with ecosystem management by conducting an exhaustive social- 
ecological assessment (Norgaad 2010). With an ecological stewardship orientation, we will be able to inform the design of management interventions to deal with the trade-offs toward more sustainable solutions; not only will research results assist in suggesting technical manipulations but they can also inform potential institutional interventions required to significantly enhance human well-being by maintaining ecosystem services along with reducing human pressure on them. Finally, it is important to recognize the predictive value and management capabilities of the conceptual framework (Fig. 1) once it is tested and fine-tuned for the particular conditions of various study sites. The quantitative calculations of ecosystem services (ES) and ecosystem integrity (EI) along with the different ecological and social trade-off (ET and ST) analysis under different land-use scenarios will allow, for example, to make decisions (cost/benefit related) regarding movement from one scenario to another.

\section{Site comparison and cross-scale interactions}

Cross-site research is a key component of ILTER work because it allows case study comparisons, the integrative testing of ideas/ hypotheses using data from a cluster of sites, and long-term or longitudinal assessments. Integration is not simply produced by assembling a data set, but also by ensuring that the focus and design of cross-site activities are jointly defined by both social and natural scientists. As we have been arguing here, the network of ILTER sites offers an ideal platform for assessing cross-site comparison including investigating cross-scale interactions among services, stakeholders, and components of well-being closely paralleling the PECS approach. We intend to assess the relative influence of human and biophysical drivers of change across a wide spectrum of social-ecological conditions, to generate and test new theories and approaches to study and deal with human-environment linkages, such as the Integrative Science for Society and Environmental (ISSE) conceptual framework (Collins et al. 2011) and heuristic approaches for transdisciplinary sustainability studies (Huutoniemi and Tapio 2014). There is always tension between broad generalities and context-specific considerations, and comparative cross-site research will require data reduction and control of variation (Preissle and LeCompte 1981, Bollen et al. 1993). Case studies create informative and detailed local narratives that, when analyzed across sites, serve to identify commonalities as well as contrasts. With long-term data on socio-ecosystem conditions at a number of sites, it becomes possible to address place-to-place development trajectory differences. Using information from multiple ILTER sites is a way to examine land-use and cover change over time as well as the relative impact of ecosystem constraints on historical and current public decisions.

Our approach will also enable cross-scale interactions among services, stakeholders, and components of well-being. Within each ILTER site, management actions can be designed to include key ecosystems and compare management regimes of local relevance. Changes in biodiversity, ecosystem integrity, and ecosystem services will occur under such a mosaic of conditions. The variables to be monitored can include the different components of biodiversity (for the key types of organisms, e.g., soil organisms, plants, etc.), and a set of ecosystem services found within each condition of the mosaic (Balvanera et al. 2014). Both the potential supply as well as the delivery of the services to people should be assessed (Tallis et al. 2012). Also, the economic and societal value of these services to different stakeholders, as well their contributions to the different components of their wellbeing, e.g., food security, protection, social relations, can be assessed (Daw et al. 2011, Chan et al. 2012, Martín-López et al. 2012). This information will help identify the relationship between ecosystem services, ecosystem transformation, and ecosystem integrity suggested in Figure 1. Bundles and trade-offs between services for contrasting conditions across the mosaic can then be explicitly linked to particular biodiversity and management conditions (Raudsepp-Hearne et al. 2010, Balvanera et al. 2014). Individual services and bundles of services can then be associated to differential preferences of services by different stakeholders and how they contribute to different components of their wellbeing (Martín-López et al. 2012, Mouchet et al. 2014).

It is particularly relevant to understand who loses and who wins under each management regime and ecosystem service bundle configuration (Leach 2013). The different scales (spatial and temporal) at which different services operate and how these services are delivered to different stakeholders, will be critical when assessing private/public winners/losers, short-term winners, and long-term losers. In this respect, the "cascade model" of ecosystem service generation and valuation (Haines-Young and Potschin 2010) proves useful, as does its extended version of the "stairways planning processes" (Spangenberg et al. 2014). ILTER sites are well positioned to provide the following information necessary to apply this approach: (1) the understanding of particular ecosystem processes, as a result of the long-term research on the structure and functional dynamics of the local ecosystem; (2) the particular use of value attribution process, as a result of the study of the living conditions, life perspectives, and economic preferences of local stakeholders who influence the recognition of the potential benefits or usefulness of a certain local ecosystem function; (3) the particular mobilization process, as a result of the identification of needs, societal demands, and actual utilization of natural resources by different local stakeholders; (4) the particular appropriation process, as a result of the analysis of human investment in the ecosystem transformation and/or processing services to generate benefits; and (5) the particular commercialization process, as a result of evaluating users keeping the ecosystem service for themselves or selling it as a market good. By implementing this cascade model it becomes easier to understand the scale effect associated to the management of ecosystem services. As documented by Spangenberg et al. (2014), using a bioenergy generation example, there is a large difference in social, economic, and environmental impact of the management of ecosystem services if it is conducted on a small-scale farm, on a large-scale farm, or on an industrialscale multinational operation:

[A]s benefits expected from one scale type cannot be expected from another one, not due to the different characteristics of use and exchange values, scaling up an operation can result in a fundamentally different kind and distribution of benefits and local impacts. Redefining ecosystem function and attributing different use values cause different definitions of ecosystem potential, trigger different mobilization and appropriation processes and provide different ecosystem services and ecosystem benefits for different beneficiaries (Spangenberg et al. 2014:29). 
With this approach and the possibility of engaging multiple study sites from different geographical regions all over the world, it will be possible to make comparisons across ILTER study sites for the identification of teleconnections (environmental interactions), globalization (socioeconomic interactions), and telecoupling (social-ecological interactions) among other phenomena (Lambin and Meyfroidt 2011, Liu et al. 2013). The relative impacts of biophysical linkages through nutrient/energy flows, invasive species, or climate change on each of the sites can be assessed on local biodiversity and service supply. The relative contribution of socioeconomic linkages through global markets, global policies, or flows of people, information, and resources on service delivery, value, and impacts of the different stakeholders can also be assessed.

Also, because monitoring is one of the main activities within ILTER sites, the engagement in social-ecological research with this proposed framework would promote, at individual sites, the monitoring of the ecological transformation process, the ecosystem services delivery, and the changes in local human wellbeing conditions. By monitoring how these variables evolve on individual sites over time within this context, e.g., plotting a large number of sites on Figure 1, we will provide information for better understanding the causal mechanisms and relationships between theses variables.

\section{Transdisciplinary research}

Liu et al. (2010) insist that we should recognize that ecosystem services research must transcend disciplinary boundaries and synthesize tools, skills, and methodologies from various disciplines if it is to fulfill its objectives. Also, they suggest that ecosystem services research has to become more problem-driven rather than tool-driven because ultimately its success will be judged on how well it facilitates real-world decision making and the conservation of natural capital. Therefore, a transdisciplinary approach is a prerequisite for our proposed ILTER/PECS collaboration. We must internalize that the knowledge driving our understanding of the world comes not only from the scientific sector, but also from other sectors of society directly involved in the particular problem that is collectively chosen as the object of study. These stakeholders hold the "expertise in pertinence" and their insight is vital in the research program (Spangenberg 2011). Research tools and approaches like "social learning" (Pahl-Wostl and Hare 2004), "participatory monitoring" (Burgos et al. 2013), "co-design" (Stappers and Sleeswijk-Visser 2007), and "citizen science" (Irwin 1995) have been developed to incorporate local and traditional knowledge into the research process. However, Maass and Equihua (2015:229) have pointed out the following:

There is an important difference between a transversal approach (working with different sectors of society) and a transdisciplinary approach (working with different sources of knowledge). The former is a development tool; the latter is an epistemological stance. We need both. However, scientists do not necessarily need to become producers, policy makers, business people or developers but, in order to conduct research in a truly transdisciplinary fashion, they have to participate in real development situations, as another stakeholder embedded in the collective. [Therefore, ] participating in transversal work is the only way to learn about this "other knowledge" requirement in real transdisciplinary research... and that is why site-based research is so important.

There are several research groups within the ILTER network who have already incorporated this transdisciplinary approach, and their experience will be a key component for the success of this potential ILTER/PECS collaboration (Haberl et al. 2006).

\section{ILTER CASE STUDIES AND HETEROGENEITY OF THE RESEARCH SITES}

As we have pointed out, changes in biodiversity and trade-offs among ecosystem services, stakeholders, and components of wellbeing are highly sensitive to local social-ecological conditions. Also, Stiglitz et al. (2009) emphasized that there is a diversity of experience among the people within each study case locality. Therefore, we should not just measure average levels of well-being within a given community, and how they change over time, but also document the diversity of people's experiences and linkages across various dimensions of people's lives. Understanding such complex relationships requires an appropriate set of case studies with highly contrasting conditions. Our proposed framework (Figs. 1 and 2) has to be formally tested on multiple cases, and the more diverse those cases can be, the stronger the test. In this respect, ILTER has much to offer to PECS. As an initial exercise, a subset of 15 ILTER sites were identified in 13 different countries on 4 continents, each currently engaged with social-ecological research (see Table 1). The lead researchers of these ILTER sites where contacted by a steering group to develop the conceptual framework and to establish the initial advocacy group for this ILTER/PECS collaboration. To characterize the social-ecological setting of this initial subset of ILTER sites, researchers from the sites answered a survey, based on their "expert judgment" following specified criteria and their definitions. The results of the survey were summarized in Table 2 and Figures 3 and 4. Although this is a small initial group, with a strong European bias, the 15 identified study cases are diverse enough to provide a broad cross-section with different policy and management drivers of ecosystem conversion; distinct trends of biodiversity change; different stakeholders' preferences for ecosystem services; and diverse components of well-being issues.

This subset of long-term research sites has a range of contrasting biomes and environmental conditions (Fig. 3), from sea level up to more than $3000 \mathrm{~m}$ above sea level. The sites include temperate (broadleaf, mixed, and coniferous forest) as well as tropical (savanna and dry deciduous forest) and Mediterranean woodland ecosystems. Mountain and low elevation ecosystems, including a sub-Antarctic peat forest, are represented. Also, there is a desert, a wetland, and different types of aquatic environments (large rivers and lakes) including a coastal ecosystem (with a rocky shore, tidal flat saltmarsh, and kelp forest and seagrass communities).

With such diversity of ecosystems, the main ecosystem services found at the different ILTER sites are also highly variable, as illustrated in Table 2. With this initial subset of 15 sites we can identify services falling in all four categories of the Millennium Ecosystem Assessment (MA 2005): support services (e.g., carbon sequestration, soil fertility, creation of green infrastructure, and maintenance of biodiversity), regulation services (e.g., climate regulation, bioregulation, flood and erosion control, fire prevention, pollination, landscape stabilization, and water quality), provision services (e.g., freshwater provision, food 
Table 1. International Long-Term Ecological Research network (ILTER) potential participant sites in an ILTER/Programme on Ecosystem Change and Society (PECS) project.

\begin{tabular}{|c|c|c|c|}
\hline & Name of Site & Main Biome & Main Land Use \\
\hline Welverdiend & $\begin{array}{l}\text { Welverdiend (SAEON), Mpumalanga, } \\
\text { South Africa. }\end{array}$ & Semiarid, subtropical savanna & $\begin{array}{l}\text { Small-scale agriculture and communal } \\
\text { rangelands. }\end{array}$ \\
\hline Niwot & $\begin{array}{l}\text { Colorado Front Range (US LTER), } \\
\text { Niwot, Colorado, USA. }\end{array}$ & $\begin{array}{l}\text { Alpine, subalpine, mountainous, low } \\
\text { elevation forests }\end{array}$ & Conservation and urban areas \\
\hline Phoenix & $\begin{array}{l}\text { Central Arizona-Phoenix (US LTER), } \\
\text { Arizona, USA. }\end{array}$ & Desert on alluvial valleys & Irrigation agriculture, urban areas \\
\hline Chamela & Chamela (Mex-LTER), Jalisco, Mexico. & $\begin{array}{l}\text { Tropical dry deciduous forest on costal } \\
\text { hills }\end{array}$ & $\begin{array}{l}\text { Agriculture and pasture lands, conservation } \\
\text { land }\end{array}$ \\
\hline Omora & $\begin{array}{l}\text { Omora Ethnobotanical Park (LTSER } \\
\text { Chile), Puerto Williams, Chile. }\end{array}$ & $\begin{array}{l}\text { Temperate forest, sub-Antarctic moorland } \\
\text { and coastal ecosystems }\end{array}$ & $\begin{array}{l}\text { Conservation, glaciers, fjords, and forest } \\
\text { lands }\end{array}$ \\
\hline Akkeshi & Akkeshi (JaLTER), Hokkaido, Japan. & $\begin{array}{l}\text { Sea grass, tidal flat, rocky shore, kelp } \\
\text { forest, saltmarsh }\end{array}$ & Fisheries and aquaculture \\
\hline Negev & $\begin{array}{l}\text { The Northern Negev (Israel LTSER } \\
\text { Platform), Israel. }\end{array}$ & $\begin{array}{l}\text { Mediterranean, semiarid desert mountain, } \\
\text { and hills }\end{array}$ & $\begin{array}{l}\text { Shrub land, planted dry land forests, } \\
\text { transition Mediterranean/arid ecosystems, } \\
\text { agriculture, urban. }\end{array}$ \\
\hline Armorique & $\begin{array}{l}\text { Zone Atelier Armorique (French LTER), } \\
\text { Brittany, France. }\end{array}$ & Temperate forest on gently rolling plains & Agriculture lands \\
\hline Cairngorms & $\begin{array}{l}\text { Cairngorms National Park (UK LTSER } \\
\text { Platform), Scotland, UK. }\end{array}$ & Mountain temperate forest & Conservation, forest, and farm lands \\
\hline Danube & $\begin{array}{l}\text { Coastal and Inland Danube deltas } \\
\text { (Romanian LTSER), Romania. }\end{array}$ & Aquatic, large rivers, wetlands (deltas) & $\begin{array}{l}\text { Conservation and sustainable use, } \\
\text { agricultural polders, built infrastructure }\end{array}$ \\
\hline Lammi & $\begin{array}{l}\text { Lammi (Finnish LTER), Southern } \\
\text { Finland. }\end{array}$ & $\begin{array}{l}\text { Coniferous forest and boreal lakes on } \\
\text { uplands }\end{array}$ & Forest and agriculture lands \\
\hline Lodz & $\begin{array}{l}\text { The City of Lodz (Poland LTSER } \\
\text { Platform), Central Poland. }\end{array}$ & $\begin{array}{l}\text { Temperate broadleaf and mixed forest on } \\
\text { lowlands }\end{array}$ & Agriculture lands, urbanized areas \\
\hline Montado & $\begin{array}{l}\text { LTsER Montado (LTER Portugal), } \\
\text { Alentejo, Portugal. }\end{array}$ & $\begin{array}{l}\text { Mediterranean forests, woodlands, and } \\
\text { scrub on plains }\end{array}$ & $\begin{array}{l}\text { Multiuse, savannah-like woodlands } \\
\text { dominated by cork and/or holm oaks }\end{array}$ \\
\hline Pilica & $\begin{array}{l}\text { The Pilica River (Poland LTSER } \\
\text { Platform), Radomszczanski, Poland. }\end{array}$ & $\begin{array}{l}\text { Temperate broadleaf and mixed forest on } \\
\text { lowlands }\end{array}$ & $\begin{array}{l}\text { Agriculture, forest, and urban areas, } \\
\text { reservoir }\end{array}$ \\
\hline Trnava & Trnava region (Slovak LTER), Slovakia. & $\begin{array}{l}\text { Temperate deciduous oak forest on } \\
\text { lowlands }\end{array}$ & Agricultural land \\
\hline
\end{tabular}

production, agricultural and pastoral goods, seafood provisioning, renewable energy, biofuel production, forage for livestock, and fuel wood), and cultural services (e.g., spiritual values, scenic landscapes, recreation, and tourism).

The level of land-use transformation is also highly variable between sites, spanning from a pristine ecosystem all the way to deeply transformed urbanized environments. Also, as is detailed in Table 2 , the sites have different policy and management drivers for ecosystem intervention. Some of them are not planned (they result from changes induced by agriculture and fishery practices, for instance), but many of them are consequences of governmental policies or induced management programs (e.g., bioenergy policies, hydropower production activities, food security programs, city development strategies, and land-use plans). Some of the drivers are slow- and long-term pressures (e.g., intensification of land use, privatization of public land, fire suppression), and others are fast land-transforming pulses (e.g., refugees from civil war, rapid urbanization processes, resettlement policies, shifts from central planning to market economy). Also, there are some policies for ecosystem protection or restoration (e.g., pay per ecosystem service programs, flood prevention act, local conservation policies).

The economic conditions, expressed in median annual income of the local population, vary more than one order of magnitude among sites (from less than US\$2000 to more than US\$50,000 $\mathrm{y}^{-1}$ ). With this diversity of social-ecological conditions, we can find all types of stakeholders within the identified ILTER sites (Table 2).
They include indigenous communities and low-income producers (i.e., peasants and subsistence farmers), as well as fishermen, aquiculturists, and more affluent producers (i.e., intensive farmers and cattle ranchers), and business people (i.e., real estate developers). Some are nongovernmental organizations and several are governmental entities (e.g., city authorities, navy officers, and forest service personal). Some sites mentioned tourists and hunters as important stakeholders, and scientists and conservationists were also cited.

With this variety of stakeholders and social-ecological settings, the main well-being issues also vary on each ILTER site (Table 2). Among the issues mentioned, there were economic aspects such as employment, sustainable tourism, low income, as well as resource limitation problems such as water availability or soil erosion. Several security issues were also identified, e.g., domestic violence and abuse of woman and children, theft, and ineffective local police, including natural hazards such as flood and drought security and fire hazards. Health problems were cited, e.g., HIV, malaria, infant mortality, as well as related drivers (urban heat island). Also cultural and general development issues were included, e.g., low education, social inclusion, place ownership, livelihoods, and aesthetics.

Finally, with regard to the capacities for social-ecological research, not all ILTER groups work at the same scale, nor do 
Table 2. Ecosystem services and socioeconomic characteristics of the International Long-Term Ecological Research network (ILTER) potential participant sites in an ILTER/Programme on Ecosystem Change and Society (PECS) collaboration project (for other sites' characteristics, please refer to Table 1 and Figures 3 and 4).

\begin{tabular}{|c|c|c|c|c|}
\hline & $\begin{array}{l}\text { Ecosystem } \\
\text { Service }\end{array}$ & Stakeholders & $\begin{array}{l}\text { Policy/Management } \\
\text { Drivers }\end{array}$ & $\begin{array}{l}\text { Well-being } \\
\text { Issues }\end{array}$ \\
\hline Welverdiend & $\begin{array}{l}\text { Fuel wood, water for domestic } \\
\text { consumption, forage for } \\
\text { livestock, and soil fertility. }\end{array}$ & Peasants. & $\begin{array}{l}\text { Lack of environmental policy } \\
\text { implementation, legacy of apartheid, and } \\
\text { resettlement policies, and refugees from civil } \\
\text { war in Mozambique. Fuel wood harvesting, } \\
\text { grazing, clearing rangelands for cash crops, } \\
\text { and urbanization. }\end{array}$ & $\begin{array}{l}\text { Health (HIV, malaria, infant } \\
\text { mortality), economic } \\
\text { productivity (low education, } \\
\text { unemployment), security } \\
\text { (domestic violence and abuse of } \\
\text { woman and children, theft) and } \\
\text { ineffective local police. }\end{array}$ \\
\hline Niwot & $\begin{array}{l}\text { Water, recreation, and } \\
\text { ecotourism. }\end{array}$ & $\begin{array}{l}\text { Residents, U.S. Forest Service, } \\
\text { and developers. }\end{array}$ & $\begin{array}{l}\text { Fire suppression, ecosystem management, } \\
\text { and energy development. Exurbanization and } \\
\text { recreation. }\end{array}$ & Fire hazards. \\
\hline Phoenix & Water, cooling, and soil fertility. & $\begin{array}{l}\text { City dwellers, real estate } \\
\text { developers, and university. }\end{array}$ & Rapid urbanization. & $\begin{array}{l}\text { Urban heat island, health, and } \\
\text { economic prosperity. }\end{array}$ \\
\hline Chamela & $\begin{array}{l}\text { Freshwater, agropastoral goods, } \\
\text { soil fertility, climate and flood } \\
\text { regulation, bioregulation, and }\end{array}$ & $\begin{array}{l}\text { Peasants, intensive farmers, } \\
\text { cattle rangers, authorities, } \\
\text { scientist, tourist developers, and }\end{array}$ & $\begin{array}{l}\text { Food security programs, pay per service } \\
\text { programs, land repartition, and emigration. } \\
\text { Pasture conversion, conservation, and }\end{array}$ & $\begin{array}{l}\text { Security, productivity loss, and } \\
\text { water availability. }\end{array}$ \\
\hline
\end{tabular}

$\begin{array}{lll}\text { scenic beauty. } & \text { NGOs. intensive agriculture in the upper basin }\end{array}$ hotspot, and scenic landscapes. fishermen, tourism operators, opened after being a navy reserve. Growth Yahgan indigenous community, and development, unplanned tourism, and conservationists. $\quad$ aquaculture and exotic invasive mammals, UNESCO Cape Horn Biosphere Reserve.

Akkeshi Seafood provisioning and water Fishermen and aquiculturists, Changes in agriculture and fisheries practices quality regulation. local town (Akkeshi) and and water quality control program. Water prefecture (Hokkaido), farmers temperature rise (climate change) and in upper river basins. eutrophication.

Negev Water retention, recreational Farmers, land management activities, primary productivity, agencies, shepherds, agriculture, grazing.

Political-demographic policies, population growth, land conversion (open space to agriculture, urban/infrastructure, forestry), grazing.

Armorique recreational users, and environmental NGOs. Soil fertility, water quality, Residents, landowners, landscape amenities, biological extensive farmers, tourists, control, carbon sequestration, foresters, and conservationists. and climate regulation.

EU agricultural policy with environmental issues (cross compliance on one hand and intensification in the other). Agriculture (nutrient leakages, pesticides, and removal of seminatural elements).

Cairngorms Cultural and regulating services Residents, landowners, land and provisioning of food and timber.

Danube Water, food, renewable energy, flood and nutrient control, and recreation and tourism.

Lammi Carbon sequestration, water purification, and recreation.

Lodz Water, tourism, leisure, aesthetics, food production, and maintenance of biodiversity.

Montado Cork and food production, water, soil fertility, carbon sequestration, tourism, biodiversity.

Pilica Agricultural production vs. water and soil quality, nutrient and water cycling, tourism and spiritual values. managers, extensive farmers, foresters, conservationists, recreationalists, and tourists

Fishermen, farmers, foresters, tourists, tourist operators, park managers, NGOs.

Farmers, forestry district, and water management district. farmers and cooperatives.

Authorities, SMEs, media, schools, governmental organizations, NGOs, scientists and developers.

EU directives (habitat, water, and bird), EU Policies (agriculture, forest, and tourist), and local interpretation of policies.

Biodiversity conservation, sustainable development, land ownership, flood protection, water transport, water quality, renewable energy, wetland restoration.

National and EU forestry and bioenergy policies. EU agricultural policy and eutrophication protection. Municipal landuse planning and management.

City development strategies and spatial planning, environmental and municipal regulations. Urbanization, demography, and land development, road development, climate change.

Farmers, cork industry, hunters, Wheat campaign (1930s), agrarian reform rural residents, nature conservationists, and tourists.

Authorities, NGOs, scientists, regional water management authority, anglers, and farmers. (after 1974 revolution), desertification, EU accession and CAP and its several reforms (since 1980). Pastoral /agriculture pressures and land abandonment.

City development and land-use plans, environment protection programs, EU directives (habitat, water, N) and flood prevention act. Urbanization, agriculture intensification, flood prevention, and tourism.

Collectivization, land repartition program, and society transformation (from central planning to market economy). Monoculture, intensive use of chemical and mechanization, and land abandonment.
Education, innovative ecotourism integrating ecology and ethics, and income potential.

Productivity (increasing income) and health.

Land rights, moderation of climate extremes, security, and economic development.

Health and economic productivity.

Employment, health, education, and economic productivity.

Employment, health, education, social security, and economic productivity.

Economic productivity, livelihoods, and health. Education of children and students (college and university). Water security, heat island, health, aesthetics, social inclusion, and place ownership, economic growth.

Economic productivity, health, water availability, social inclusion (e.g., employment), and place ownership.

Health, productivity, flood and drought prevention, and sustainable tourism.

Health, economic productivity, quality of environment, recreation areas. 
Fig. 3. Social-ecological heterogeneity of the 15 International Long-Term Ecological Research networks (ILTER) identified as potential participants in a ILTER/Programme on Ecosystem Change and Society (PECS) project. For more information of the sites, please refer to Tables 1 and 2. Marker's shape refers to site's continent (star is Africa, squares are Americas, triangle is Asia, and circles are Europe).

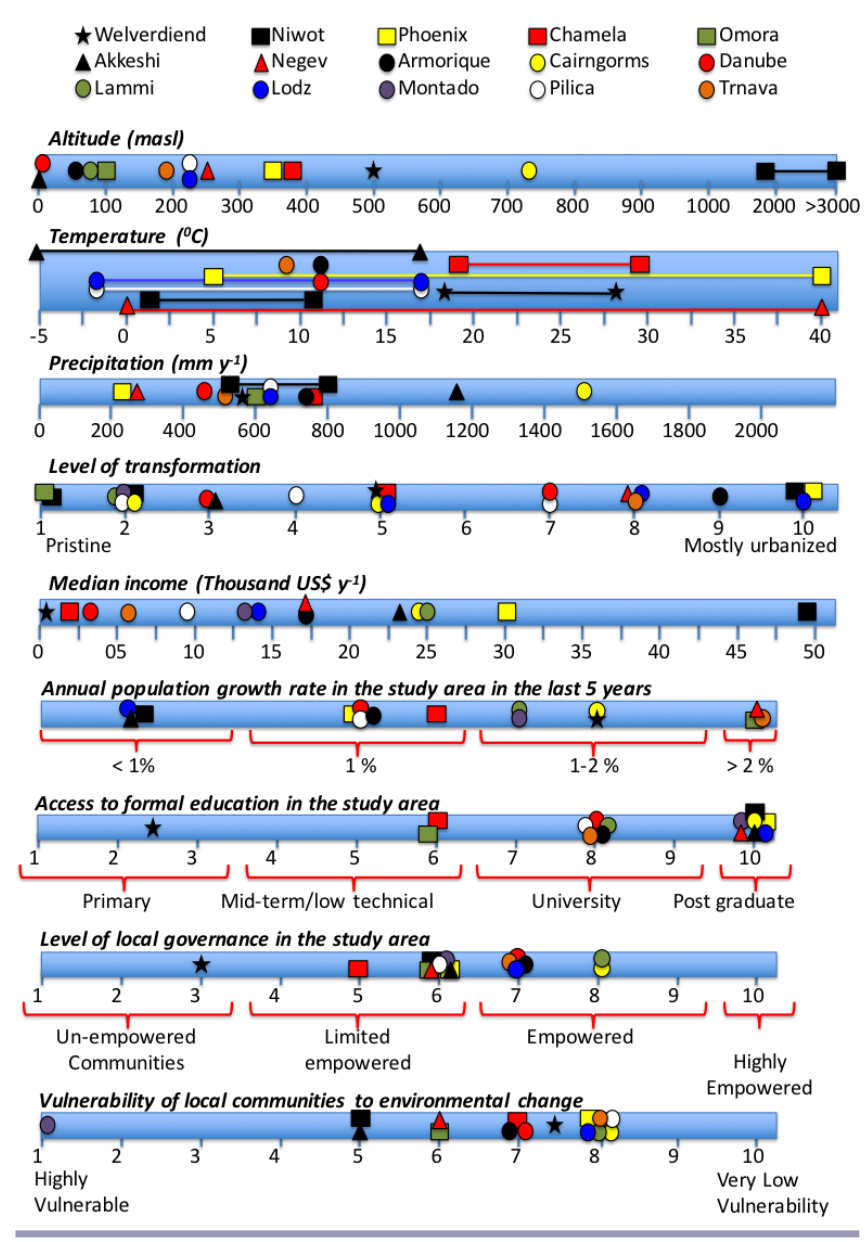

they have the same epistemological approach or level of involvement with the management process. However, within the 15 ILTER sites identified as potential participants in a PECS initiative, most groups participate at national and regional (several countries) cross-scales analysis (see Fig. 4). Also, multiand interdisciplinary approaches are common among the groups, and several of them already are engaged in transdisciplinary research. It should be emphasized that all groups are committed to conduct applied research activities and most of them already are involved in outreach programs and actively participate in local/regional planning and policy development of ecosystem stewardship. Finally, all participants are committed to working toward coordination and harmonization of research goals and data collection protocol. Recently, 22 European ILTER members were awarded a European Union Horizon 2020 grant to develop their infrastructures toward these goals.
Fig. 4. Research activity of the 15 ILTER case-studies identified as potential participants in a ILTER/PECS project. For more information of the sites, please refer to Tables 1 and 2, and Figure 3. Marker's shape refers to site's continent (star is Africa, squares are Americas, triangle is Asia and circles are Europe).

$\begin{array}{lllll}\star \text { Welverdiend } & \square \text { Niwot } & \square \text { Phoenix } & \square \text { Chamela } & \square \text { Omora } \\ \Delta \text { Akkeshi } & \Delta^{\text {Negev }} & \text { OArmorique } & \text { OCairngorms } & \text { ODanube } \\ \text { OLammi } & \text { OLodz } & \text { OMontado } & \text { OPilica } & \text { OTrnava }\end{array}$
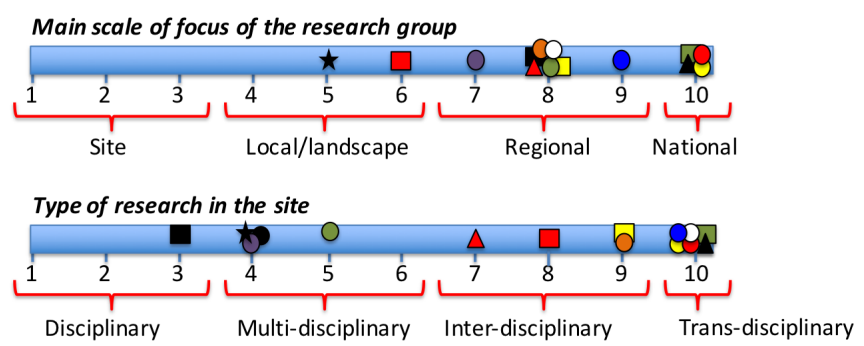

Level of participation in the local ecosystem stewardship

Bridging with the rest of the network

In the effort to build the capacity of ILTER sites to engage in cross-site socio-ecosystem research, it is important to recognize that sites and member networks are at different stages of development. To engage in network-level socio-ecosystem research, it would be helpful to explore how those sites with more experience can help those just exploring the integration of a social dimension in their program. This could include an institutionalized set of incentives that encourage and develop the capacity of sites to engage in socio-ecosystem research and to participate in cross-site studies. The 15 ILTER sites identified to participating in this initiative represent no more than $2 \%$ of the current LTER members' sites (currently of more than 600). Also, a new "affiliated site" status has been established within ILTER membership to enable the collaboration with research groups not formally belonging to an ILTER national network. Therefore, we are only scratching the "tip of the iceberg" of potential participating sites. All of these 15 sites were selected because they have previously collaborated on broad scale comparisons of ecosystem services (Vihervaara et al. 2013), which provided a solid basis for the presented work. Also, because all these sites have strong links to their national networks, they will be able to disseminate the PECS philosophy within each country. This is important because linkage to the broader ILTER network is where the real potential contribution of this initiative can be utilized. Of course not all ILTER sites currently conduct socialecological research, however, most of them are convinced of its importance and with this pilot research program, the already identified sites will bridge the idea to the rest of the ILTER network, fostering the LT"E"R to the LT"SE"R transition (Haberl et al. 2006, Singh et al. 2013, Maass and Equihua 2015). 
Although economic resources are always the central element of concern among research groups, our experiences have shown that organizational issues and human resources are, by far, stronger limiting factors for long-term research. By fostering networking collaboration and with a strong interest in capacity building, LTER groups should improve their chances of gaining funding for socio-ecosystem research. By avoiding centralizing the economic resources, we maintain independence and allow for an easy involvement of new groups.

\section{FINAL REMARKS}

Concerning the current scientific knowledge of the links between ecosystem services and human well-being, one of the critical gaps identified by PECS include "the need for understanding how social-ecological systems evolve over time and respond to policy interventions" (Carpenter et al. 2012:2). The large-scale scope, site-based approach, and long-term commitment of the ecosystem-level research of ILTER network, make it an excellent platform to tackle this problem, particularly by identifying and monitoring the changes in biodiversity and trade-offs among ecosystem services, stakeholders, and components of well-being, which is our major focus in this potential ILTER/PECS collaboration. The synergy of colleagues working together across sites will facilitate cross-fertilization of existing ideas, leading to the development of new questions, the generation of new theories, and the testing and refinement of existing ones. The value of this comparative research in the context of an ILTER/PECS collaboration will further promote the, already in progress, transition from LT"E"R to LT"SE"R in which socio-ecosystem and transdisciplinary approaches are being implemented as an essential step in the natural evolution of the scientific agenda toward sustainability. With more than 600 sites spread all over the world representing a high variety of social-ecological settings, ILTER network becomes an excellent tool to disseminate the PECS philosophy. The lines presented here draw a route to crystallize this important long-term scientific collaboration.

Responses to this article can be read online at: http://www.ecologyandsociety.org/issues/responses. $\mathrm{php} / 8587$

\footnotetext{
Acknowledgments:

The authors thank Raúl Ahedo, Sandokan Barajas, Cristina Branquinho, Atzimba López, and Lyliana Rentería who helped with the preparation of the manuscript. We also thank a couple of anonymous reviewers for their comments and suggestions. The document was prepared during a visit by Manuel Maass to the Finnish Environment Institute (SYKE) with a DGAPA-UNAM sabbatical scholarship and within CONACYT support for ILTER. Some of the insights we have achieved were possible thanks to the partial support of the European Union Seventh Framework Programme (FP7/2007-2013) under grant agreement $n^{\circ} 283093$ The Role Of Biodiversity In Climate Change Mitigation ( ROBIN). The partial support of the project no: 308428 (OpenNESS) under the same Programme is also acknowledged. Data from Chamela LTER derives from project SEP-CONACYT 179045. Data from LTER Montado derives from projects FCT-LTER/BIA-
}

BEC10048/2009 and OPERAs (FP7-Grand Agreement 308393). Data from Omora LTER derive from grants IEB-ICM P05-002 and IEB-CONICYT PFB-23. Patrick Bourgeron acknowledges primary support from the US NSF Coupled Natural Human Systems Program (DEB-1115068), as well as additional funding provided by a Water Sustainability and Climate grant (USDA ANIF-2012/67003/19802) and the Niwot Ridge Long-Term Ecological Research Program (US NSF DEB 9810218).

\section{LITERATURE CITED}

Aherne, J., M. Posch, M. Forsius, A. Lehtonen, and K. Härkönen 2012. Impacts of forest biomass removal on soil nutrient status under climate change: a catchment-based modelling study for Finland. Biogeochemistry 107:471-488. http://dx.doi.org/10.1007/ s10533-010-9569-4

Andrew, R. 2014. Socio-economic drivers of change in the Arctic. AMAP Technical Report No. 9 2014. Arctic Monitoring and Assessment Programme (AMAP), Oslo, Norway.

Balvanera, P., I. Siddique, L. Dee, A. Paquette, F. Isbell, A Gonzalez, J. E. Byrnes, M. I. O’Connor, B. A. Hungate, and J. N. Griffin. 2014. Linking biodiversity and ecosystem services: current uncertainties and the necessary next steps. BioScience 64:49-57. http://dx.doi.org/10.1093/biosci/bit003

Bollen, K. A., B. Entwisle, and A. S. Alderson. 1993. Macrocomparative research methods. Annual Review of Sociology 19:321-351. http://dx.doi.org/10.1146/annurev. $\underline{\text { so. } 19.080193 .001541}$

Bridgewater, P., R. E. Kim, and K. Bosselmann. 2014. Ecological integrity: a relevant concept for international environmental law in the Anthropocene? Yearbook of International Environmental Law 25(1):61-78. http://dx.doi.org/10.1093/yiel/yvv059

Burgos, A., R. Páez, E. Carmona, and H. Rivas. 2013. A systems approach to modeling community-based environmental monitoring: a case of participatory water quality monitoring in rural Mexico. Environmental Monitoring and Assessment 185 (12):10297-10316. http://dx.doi.org/10.1007/s10661-013-3333-X

Cardinale, B. J., J. E. Duffy, A. Gonzales, D. U. Hooper, C. Perrings, P. Venail, A. Narwani, G. M. Mace, D. Tilman, D. A. Wardle, A. P. Kinzig, G. C. Daily, M. Loreau, J. B. Grace, A. Larigauderie, D. S. Srivastava, and S. Naeem. 2012. Biodiversity loss and its impact on humanity. Nature 486:59-67. http://dx.doi. org/10.1038/nature 11148

Carpenter, S. R., C. Folke, A. Norström, O. Olsson, L. Schultz, B. Agarwal, P. Balvanera, B. Campbell, J. C. Castilla, W. Cramer, R. DeFries, P. Eyzaguirre, T. P. Hughes, S. Polasky, Z. Sanusi, R. Scholes, and M. Spierenburg. 2012. Program on ecosystem change and society: an international research strategy for integrated social-ecological systems. Current Opinion on Environmental Sustainability 4(1):1-5. http://dx.doi.org/10.1016/j.cosust.2012.01.001

Carpenter S. R., H. A. Mooney, J. Agard, D. Capistrano, R. S. Defries, S. Díaz, T. Dietz, A. K. Duraiappah, A. Oteng-Yeboah , H. M. Pereira, C. Perrings, W. V. Reid, J. Sarukhan, R. J. Scholes, and A. Whyte. 2009. Science for managing ecosystem services: beyond the Millennium Ecosystem Assessment. Proceedings of the National Academy of Sciences of the United States of America 106(5):1305-1312. http://dx.doi.org/10.1073/pnas.0808772106 
Chan, K. M. A., A. D. Guerry, P. Balvanera, S. Klain, T. Satterfield, X. Basurto, A. Bostrom, R. Chuenpagdee, R. Gould, and B. S. Halpern. 2012. Where are cultural and social in ecosystem services? A framework for constructive engagement. BioScience 62:744-756. http://dx.doi.org/10.1525/bio.2012.62.8.7

Collins, S. L., S. R. Carpenter, S. M. Swinton, D. E. Orenstein, D. L. Childers, T. L. Gragson, N. B. Grimm, J. M. Grove, S. L. Harlan, J. P. Kaye, A. K. Knapp, G. P. Kofinas, J. J. Magnuson, W. H. McDowell, J. M. Melack, L. A. Ogden, G. P. Robertson, M. D. Smith, and A. C. Whitmer. 2011. An integrated conceptual framework for long-term social-ecological research. Frontiers in Ecology and the Environment 9: 351-357. http://dx.doi. org/10.1890/100068

Costanza, R., and S. Farber. 2002. Introduction to the special issue on the dynamics and value of ecosystem services: integrating economic and ecological perspectives. Ecological Economics 41:367-373. http://dx.doi.org/10.1016/S0921-8009(02)00087-3

Daw, T., K. Brown, S. Rosendo, and R. Pomeroy. 2011. Applying the ecosystem services concept to poverty alleviation: the need to disaggregate human well-being. Environmental Conservation 38:370-379. http://dx.doi.org/10.1017/S0376892911000506

de Groot, R. S., R. Alkemade, L. Braat, L. Hein, and L. Willemen. 2010. Challenges in integrating the concept of ecosystem services and values in landscape planning, management and decisionmaking. Ecological Complexity 7(3):260-272. http://dx.doi. org/10.1016/j.ecocom.2009.10.006

Díaz, S., S. Demissew, J. Carabias, C. Joly, M. Lonsdale, N. Ash, A. Larigauderie, J. R. Adhikari, S. Arico, A. Báldi, et al. 2015. The IPBES conceptual framework - connecting nature and people. Current Opinion in Environmental Sustainability 14:1-16. http://dx.doi.org/10.1016/j.cosust.2014.11.002

Dick, J., A. Al-Assaf, C. Andrews, R. Díaz-Delgado, E. Groner, L. Halada, Z. Izakovičová, M. Kertés, F. Khoury, D. Krasić, K. Krauze, G. Matteucci, V. Melecis, M. Mirtl, D. E. Orenstein, E. Preda, M. Santos-Reis, R. I. Smith, A. Vadineanu, S. Veselić, and P. Vihervaara. 2014. Ecosytem services: a rapid assessment method tested at 35 sites of the LTER-Europe network. Ekologia 33(3):217-231. http://dx.doi.org/10.2478/eko-2014-0021

Dick, J. M., R. I. Smith, and E. M. Scott. 2011. Ecosystem services and associated concepts. Environmetrics 22:598-607. http://dx. doi.org/10.1002/env.1085

Dornelas, M., N. J. Gotelli, B. McGill, H. Shimadzu, F. Moyes, C. Sievers, and A. E. Magurran. 2014. Assemblage time series reveal biodiversity change but not systematic loss. Science 344 (6181):296-299. http://dx.doi.org/10.1126/science.1248484

Ehrlich, P. R., P. M. Kareiva, and G. C. Daily. 2012. Securing natural capital and expanding equity to rescale civilization. Nature 486:68-73 http://dx.doi.org/10.1038/nature11157

Equihua Zamora, M., N. García Alaniz, O. Pérez-maqueo, G. Benítez Badillo, M. Kolb, M., M. Schmidt, and J. L. Álvarez Palacios. 2014. Integridad ecológica como indicador de la calidad ambiental. Pages 695-718 in C. A. González Zuarth, A. Vallarino, J. C. Pérez Jiménez, and A. M. Low Pfeng, editors. Bioindicadores: guardianes de nuestro futuro ambiental. El Colegio de la Froentera Sur (ECOSUR), Mexico City, Mexico.
Farber, S., R. Costanza, D. L. Childers, J. Erickson, K. Gross, M. Grove, C. S. Hopkinson, J. Kahn, S. Pincetl, A. Troy, P. Warren, and M. Wilson. 2006. Linking ecology and economics for ecosystem management. BioScience 56(2):121-133. http://dx.doi. org/10.1641/0006-3568(2006)056[0121:1eaefe]2.0.co;2

Forsius, M., S. Anttila, L. Arvola, I. Bergström, H. Hakola, H. I. Heikkinen, J. Helenius, M. Hyvärinen, K. Jylhä, J. Karjalainen, T. Keskinen, K. Laine, E. Nikinmaa, P. Peltonen-Sainio, K. Rankinen, M. J. Reinikainen, H. Setälä, and J. Vuorenmaa. 2013. Impacts and adaptation options of climate change on ecosystem services in Finland: a model based study. Current Opinion in Environmental Sustainability 5:26-40. http://dx.doi.org/10.1016/j. cosust.2013.01.001

Fu, B., and M. Forsius. 2015. Ecosystem services modeling in contrasting landscapes. Landscape Ecology 30:375-379. http://dx. doi.org/10.1007/s10980-015-0176-6

Future Earth 2014. Future Earth strategic research agenda 2014. International Council for Science, Paris, France.

Global Earth Observation System of Systems (GEOSS). 2005. Global Earth Observation System of Systems (GEOSS): 10-year implementation plan reference document. Group on Earth Observations, Geneva, Switzerland.

Gómez-Baggethun, E., and R. de Groot. 2007. Capital natural y funciones de los ecosistemas: explorando las bases ecológicas de la economía. Ecosistemas 16(3):4-14.

Grimm, N. B., J. M. Grove, S. T. A. Pickett, and C. L. Redman. 2000. Integrated approaches to long-term studies of urban ecological systems. BioScience 50(7):571-584. http://dx.doi. org/10.1007/978-0-387-73412-5_8

Haberl, H., V. Winiwarter, K. Andersson, R. U. Ayres, C. Boone, A. Castillo, G. Cunfer, M. Fischer-Kowalski, W. R. Freudenburg, E. Furman, R. Kaufmann, F. Krausmann, E. Langthaler, H. Lotze-Campen, M. Mirtl, C. L. Redman, A. Reenberg, A. Wardell, B. Warr, and H. Zechmeister. 2006. From LTER to LTSER: conceptualizing the socioeconomic dimension of longterm socioecological research. Ecology and Society 11(2):13. [online] URL: http://www.ecologyandsociety.org/vol11/iss $2 /$ $\underline{\operatorname{art13/}}$

Haines-Young, R., and M. Potschin. 2010. The links between biodiversity, ecosystem services and human well-being. Pages 110-139 in D. G. Raffaelli and C. L. J. Frid, editors. Ecosystem ecology: anew synthesis. Cambridge University Press, Cambridge, UK. http://dx.doi.org/10.1017/cbo9780511750458.007

Holmberg, M., A. Akujärvi, S. Anttila, L. Arvola, I. Bergström, K. Böttcher, X. Feng, M. Forsius, I. Huttunen, M. Huttunen, Y. Laine, H. Lehtonen, J. Liski, L. Mononen, K. Rankinen, A. Repo, V. Piirainen, P. Vanhala, and P. Vihervaara. 2015. ESLab application to a boreal watershed in southern Finland: preparing for a virtual research environment of ecosystem services. Landscape Ecology 30(3):561-577. http://dx.doi.org/10.1007/ $\underline{\mathrm{s} 10980-014-0122-\mathrm{Z}}$

Huutoniemi, K., and P. Tapio. 2014. Transdisciplinary sustainability studies: a heuristic approach. Routledge, New York, New York, USA. 
Irwin, A. 1995. Citizen science: a study of people, expertise and sustainable development. Psychology Press, Routledge, New York, New York, USA.

Kinzig, A. P, P. Ryan, M. Etienne, H. Allison, T. Elmqvist, and B. H. Walker. 2006. Resilience and regime shifts: assessing cascading effects. Ecology and Society 11(1):20. [online] URL: http://www.ecologyandsociety.org/vol11/iss1/art20/

Lambin, E. F., and P. Meyfroidt. 2011. Global land use change, economic globalization, and the looming land scarcity. Proceedings of the National Academy of Sciences of the United States of America 108(9):3465-3472. http://dx.doi.org/10.1073/ pnas. 1100480108

Leach, M. 2013. Pathways to sustainability: building political strategies. Pages 234-243 in Worldwatch Institute, editor. State of the World 2013: is sustainability still possible? Island Press, Washington, D.C., USA. http://dx.doi.org/10.5822/978-1-61091-458-1_22

Levin, S. A. 1999. Fragile dominion: complexity and the commons. Helix Books, Cambridge, Massachusetts, USA.

Li, B., T. Parr, and R. Rozzi. 2015. Geographical and thematic distribution of publications generated at the International LongTerm Ecological Research Network (ILTER) Sites. Pages 195-216 in R. Rozzi, F. S. Chapin III, J. B. Callicott, S. T. A. Pickett, M. E. Power, J. J. Armesto, and R. H. May Jr, editors. Earth stewardship: linking ecology and ethics in theory and practice. Springer, Dordrecht, The Netherlands. http://dx.doi. org/10.1007/978-3-319-12133-8 13

Liu, J., V. Hull, M. Batistella, R. DeFries, T. Dietz, F. Fu, T. W. Hertel, R. C. Izaurralde, E. F. Lambin, S. Li, L. A. Martinelli, W. J. McConnell, E. F. Moran, R. Naylor, Z. Ouyang, K. R. Polenske, A. Reenberg, G. de Miranda Rocha, C. S. Simmons, P. H. Verburg, P. M. Vitousek, F. Zhang, and C. Zhu. 2013. Framing sustainability in a telecoupled world. Ecology and Society 18 (2):26. http://dx.doi.org/10.5751/ES-05873-180226

Liu, S., R. Costanza, S. Farber, and A. Troy. 2010. Valuing ecosystem services: theory, practice, and the need for a transdisciplinary synthesis. Annals of the New York Academy of Science 1185:54-78. http://dx.doi.org/10.1111/j.1749-6632.2009.05167. $\underline{\mathrm{x}}$

Maass, J. M. 2012. El manejo sustentable de socioecosistemas. Pages 89-99 in J. L. Calva, coordinator. Cambio climático y politicas de desarrollo sustentable. Tomo 14 de la colección Análisis Estratégico para el Desarrollo. Juan Pablos EditorConsejo Nacional de Universitarios, Coyoacán, México.

Maass, J. M., P. Balvanera, A. Castillo, G. C. Daily, H. A. Mooney, P. Ehrlich, M. Quesada, A. Miranda, V. J. Jaramillo, F. GarcíaOliva, A. Martínez-Yrizar, H. Cotler, J. López-Blanco, A. PérezJiménez, A. Búrquez, C. Tinoco, G. Ceballos, L. Barraza, R. Ayala, and J. Sarukhán. 2005. Ecosystem services of tropical dry forests: insights from long-term ecological and social research on the Pacific Coast of Mexico. Ecology and Society 10(1):17. [online] URL: http://www.ecologyandsociety.org/vol10/iss1/art17/

Maass, M., and M. Equihua. 2014. La Red Internacional de Investigación Ecológica a Largo Plazo a 20 años de su creación: sus avances y retos. Bosque 35(3):415-419. http://dx.doi. org/10.4067/S0717-92002014000300016
Maass, M., and M. Equihua. 2015. Earth stewardship, socioecosystems, the need for a transdisciplinary approach and the role of the international Long Term Ecological Research network (ILTER). Pages 217-233 in R. Rozzi, F. S. Chapin III, J. B. Callicott, S. T. A. Pickett, M. E. Power, J. J. Armesto, and R. H. May Jr, editors. Earth stewardship: linking ecology and ethics in theory and practice. Springer, Dordrecht, The Netherlands.

Maes, J., B. Egoh, L. Willemen, C. Liquete, P. Vihervaara, J. P. Schägner, B. Grizzetti, E. G. Drakou, A. LaNotte, G. Zulian, F. Bouraoui, M. L. Paracchini, L. Braat, and G. Bidoglio. 2012. Mapping ecosystem services for policy support and decision making in the European Union. Ecosystem Services 1:31-39. http://dx.doi.org/10.1016/j.ecoser.2012.06.004

Martín-López, B., I. Iniesta-Arandia, M. García-Llorente, I. Palomo, I. Casado-Arzuaga, D. G. D. Amo, E. GómezBaggethun, E. Oteros-Rozas, I. Palacios-Agundez, B. Willaarts, J. A. González, F. Santos-Martín, M. Onaindia, C. LópezSantiago, and C. Montes. 2012. Uncovering ecosystem service bundles through social preferences. PLoS ONE 7(6):e38970. http://dx.doi.org/10.1371/journal.pone.0038970

Millennium Ecosystem Assessment (MA). 2005. Millennium Ecosystem Assessment: ecosystems and human well-being: synthesis. Island Press, Washington, D.C., USA.

Mooney, H., E. Lariguaderie, M. Cesario, T. Elmquist, O. HoeghGuldberg, S. Lavorel, G. M. Mace, M. Palmer, R. Scholes, and T. Yahara. 2009. Biodiversity, climate change, and ecosystem services. Current Opinion in Environmental Sustainability 1:46-54. http://dx.doi.org/10.1016/j.cosust.2009.07.006

Mouchet, M., P. Lamarque, B. Martín-López, E. Crouzat, P. Gos, C. Byczek, and S. Lavorel. 2014. An interdisciplinary methodological guide for quantifying associations between ecosystem services. Global Environmental Change 28:298-308. http://dx.doi.org/10.1016/j.gloenvcha.2014.07.012

Naeem, S., J. E. Duffy, and E. Zavaleta. 2012. The functions of biological diversity in an age of extinction. Science 336 (6087):1401-1406. http://dx.doi.org/10.1126/science.1215855

Norgaad, R. B. 2010. Ecosystem services: from eye-opening metaphor to complexity blinder. Ecological Economics 69:1219-1227. http://dx.doi.org/10.1016/j.ecolecon.2009.11.009

Ohtsuka, T., N. Saigusa, and H. Koizumi. 2009. On linking multiyear biometric measurements of tree growth with eddy covariance-based net ecosystem production. Global Change Biology 15:1015-1024. http://dx.doi.org/10.1111/j.1365-2486.2008.01800. $\underline{\mathrm{X}}$

Pahl-Wostl, C., and M. Hare. 2004. Processes of social learning in integrated resources management. Journal of Community \& Applied Social Psychology 14:193-206. http://dx.doi.org/10.1002/ casp. 774

Parr, T. 2013. The international long-term ecological research network and its role in global research and policy. Pages 37-56 in M. Tabarelli, C. F. Duarte da Rocha, H. P. Romanowski, O. Rocha, and L. D. de Lacerda, editors. PELD - CNPq: dez anos do Programa de Pesquisas Ecológicas de Longa Duração do Brasil: achados, lições e perspectivas. Editora Universitária da UFPE, Recife, Brazil. 
Pereira, H. M., S. Ferrier, M. Walters, G. N. Geller, R. H. G. Jongman, R. J. Scholes, M. W. Bruford, N. Brummitt, S. H. M. Butchart, A. C. Cardoso, N. C. Coops, E. Dulloo, D. P. Faith, J. Freyhof, R. D. Gregory, C. Heip, R. Höft, G. Hurtt, W. Jetz, D. S. Karp, M. A. McGeoch, D. Obura, Y. Onoda, N. Pettorelli, B. Reyers, R. Sayre, J. P. W. Scharlemann, S. N. Stuart, E. Turak, M. Walpole, and M. Wegmann. 2013. Essential biodiversity variables. Science 339(6117):277-278. http://dx.doi.org/10.1126/science.1229931

Pereira, H. M., P. W. Leadley, V. Proença, R. Alkemade, J. P. Scharlemann, J. F. Fernandez-Manjarrés, M. B. Araújo, P. Balvanera, R. Biggs, W. W. L. Cheung, L. Chini, H. D. Cooper, E. L. Gilman, S. Guénette, G. C. Hurtt, H. P. Huntington, G. M. Mace, T. Oberdorff, C. Revenga, P. Rodrigues, R. J. Scholes, U. R. Sumaila, and M. Walpole. 2010. Scenarios for global biodiversity in the 21 st century. Science 330:1496-1501. http://dx. doi.org/10.1126/science.1196624

Peterson, M. J., D. M. Hall, A. M. Feldpausch-Parker, and T. R. Peterson. 2010. Obscuring ecosystem function with application of the ecosystem services concept. Conservation Biology 24 (1):113-119. http://dx.doi.org/10.1111/j.1523-1739.2009.01305.x

Preissle, J. G., and D. LeCompte. 1981. Problems of reliability and validity in ethnographic research. Review of Educational Research 52(1):31-60.

Raudsepp-Hearne, C., G. D. Peterson, and E. M. Bennett. 2010. Ecosystem service bundles for analyzing trade-offs in diverse landscapes. Proceedings of the National Academy of Sciences of the United States of America 107:5242-5247. http://dx.doi. org/10.1073/pnas.0907284107

Redman, C. L., J. M. Grove, and L. H. Kuby. 2004. Integrating social science into the long-term ecological research (LTER) network: social dimensions of ecological change and ecological dimensions of social change. Ecosystems 7(2):161-171. http://dx. doi.org/10.1007/s10021-003-0215-Z

Reyers, B., R. Biggs, G. S. Cumming, T. Elmqvist, A. P. Hejnowicz, and S. Polasky. 2013. Getting the measure of ecosystem services: a social-ecological approach. Frontiers in Ecology and the Environment 11(5):268-273. http://dx.doi.org/10.1890/120144

Rozzi, R. 2012. Biocultural ethics: recovering the vital links between the inhabitants, their habits, and habitats. Environmental Ethics 34(1):27-50. http://dx.doi.org/10.5840/enviroethics20123414

Rozzi, R., J. J. Armesto, J. R. Gutiérrez, F. Massardo, G. E. Likens, C. B. Anderson, A. Poole, K. P. Moses, E. Hargrove, A. O. Mansilla, J. H. Kennedy, M. Willson, K. Jax, C. G. Jones, J. B. Callicott, and M. T. K. Arroyo. 2012. Integrating ecology and environmental ethics: Earth stewardship in the southern end of the Americas. BioScience 62(3):226-236. http://dx.doi.org/10.1525/ bio.2012.62.3.4

Schröter, D., W. Cramer, R. Leemans, I. C. Prentice, M. B. Araújo, N. W. Arnell, A. Bondeau, H. Bugmann, T. R. Carter, C. A. Gracia, A. C. De La Vega-Leinert, M. Erhard, F. Ewert, M. Glendining, J. I. House, S. Kankaanpää, R. J. T. Klein, S. Lavorel, M. Lindner, M. J. Metzger, J. Meyer, T. D. Mitchell, I. Reginster, M. Rounsevell, S. Sabaté, S. Sitch, B. Smith, J. Smith, P. Smith, M. T. Sykes, K. Thonicke, W. Thuiller, G. Tuck, S. Zaehle, and B. Zierl. 2005. Ecosystem service supply and vulnerability to global change in Europe. Science 310:1333-1337. http://dx.doi. $\underline{\text { org/10.1126/science. } 1115233}$
Shibata, H., and P. Bourgeron. 2011. Challenge of international long-term ecological research network (ILTER) for socioecological land sciences. Global Land Project NEWS 7:13-14. [online] URL: http://www.globallandproject.org/arquivos/ GLP NEWS 07.pdf

Singh, S. J., H. Haberl, M. Chertow, M. Mirtl, and M. Schmid. 2013. Long term socio-ecological research. Springer, Dordrecht, The Netherlands. http://dx.doi.org/10.1007/978-94-007-1177-8

Spangenberg, J. H. 2011. Sustainability science: a review, an analysis and some empirical lessons. Environmental Conservation 38(3):275-287. http://dx.doi.org/10.1017/s0376892911000270

Spangenberg, J. H., C. von Haaren, and J. Settele. 2014. The ecosystem service cascade: further developing the metaphor. Integrating societal processes to accommodate social processes and planning, and the case of bioenergy. Ecological Economics 104:22-32. http://dx.doi.org/10.1016/j.ecolecon.2014.04.025

Stappers, P. J., and F. Sleeswijk-Visser. 2007. Bringing participatory techniques to industrial design engineers. International Conference on Engineering and Product Design Education. Northumbria University, Newcastle Upon Tyne, UK.

Stiglitz, J., A. K. Sen, and J. P. Fitoussi. 2009. The measurement of economic performance and social progress revisited: reflections and overview. SciencesPo Archives Hal-01069384. [online] URL: https://hal-sciencespo.archives-ouvertes.fr/hal-01069384

Tallis, H., H. Mooney, S. Andelman, P. Balvanera, W. Cramer, D. Karp, S. Polasky, B. Reyers, T. Ricketts, S. Running, K. Thonicke, B. Tietjen, and A. Walz. 2012. A global system for monitoring ecosystem service change. BioScience 62:977-986. http://dx.doi. org/10.1525/bio.2012.62.11.7

UK National Ecosystem Assessment (UK NEA). 2011. The UK National Ecosystem Assessment technical report. UNEPWCMC, Cambridge, UK.

Vadineanu, A., M. Adamescu, R. Vadineanu, S. Cristofor, and C. Negrei. 2003. Past and future management of Lower Danube Wetlands System: a bioeconomic appraisal. Journal of Interdisciplinary Economics 14:415-447. http://dx.doi. org/10.1177/02601079X03001400407

Vadineanu, A. 2007. The ecosystem approach applied to the management of the coastal socio-ecological systems. Pages 199-224 in I. E. Gonenc, V. G. Koutitonsky, B. Rashleigh, R. B. Ambrose Jr., and J. P. Wolflin, editors. Assessment of the fate and effects of toxic agents on water resources. Springer, Dordrecht, The Netherlands. http://dx.doi.org/10.1007/978-1-4020-5528-7 9

Vaughan, H. H., R. B. Waide, J. M. Maass, and E. Ezcurra. 2007. Developing and delivering scientific information in response to emerging needs. Frontiers in Ecology and the Environment 5(4):1-4 http://dx.doi.org/10.1890/1540-9295(2007)5[w8:dadsii]2.0.co;2

Vihervaara, P., D. D'Amato, M. Forsius, P. Angelstam, C. Baessler, P. Balvanera, B. Boldgiv, P. Bourgeron, J. Dick, R. Kanka, S. Klotz, M. Maass, V. Melecis, P. Petrik, H. Shibata, J. Tang, J. Thompson, and S. Zacharias. 2013. Using long-term ecosystem service and biodiversity data to study the impacts and adaptation options in response to climate change: insights from the global ILTER sites network. Current Opinion in Environmental Sustainability 5(1):53-66. http://dx.doi.org/10.1016/j.cosust.2012.11.002 